\title{
Research on the Behavior of Some Maize Hybrids (Zea Mays) under the Influence of Technological Linksat Fundulea, Călărasi Country
}

\author{
Valentina Gabriela LAZIN $^{1}$, Costica CIONTU ${ }^{1}$ \\ ${ }^{1}$ University of Agronomic Science and Veterinary Medicine, 59 Mărășești Street, 011464 Bucharest, \\ Romania; \\ * corresponding author: valentinagabrielalazin@yahoo.ro \\ Bulletin USAMV series Agriculture 72(1)/2015 \\ Print ISSN 1843-5246; Electronic ISSN 1843-5386 \\ DOI 10.15835/buasvmcn-agr: 11158
}

\begin{abstract}
The main aim of this research theme is to determine the best maize hybrids (Zea mays L. convar. Dentiformis) suitable for the southern area of Romania, thatin terms of applying the most appropriate technological links to determine the achievement of high and stable harvests. Plant cultivation has been achieved in optimal technology, specific to the site culture in not irrigated variant, the studied genotypes consisting in two Romanian hybrids: Partizanand Opal. The experiment was located on a uniform land considering the fertility and landscape, on a chernozem soil, in an experimental field belonging to NARDI Fundulea. The experimental results were statistically processed using the method of variance analysis. Conclusions consist of analysis of variance on the influence of soil tillage, fertilization and use of hybrid in maize harvest in terms of the climate in 2012.
\end{abstract}

Keywords: harvest, technological links, Zea mays.

\section{INTRODUCTION}

Plant of maize(Zea mays)is the most surprising system nature has for energy storage. From a seed weighs about one third of a gram, rise and develop in about 10 weeks a plant 2 meters high, and after only eight weeks it will produce 600-1000 grains. Due to the chemical composition of all its parts, maize is of great agricultural significance, being basic forage in feed and a valuable raw material for human nutrition.

Succeeding maize crops implemented in obtaining reliable quantitative and qualitative harvests is dependent on ensuring and compliance with all technological links (Bîlteanu, 1989).

The main technological parameters are:

- location of culture;

- fertilizer application;

- irrigation;

- soil tillage;
- seed and sowing (planted hybrid, optimum density, sowing period);

- maintenance of cultures (control of weeds, pests and diseases).

The experiments were mainly aimed the behavior research on maize hybrids under the influence of various technological sequences, in the soil and climate conditions from southern Romania. To determine the optimal technology of maize cultivation was investigated how it reacts to different tillage methods, on different fertilization agro funds, different hybrids, as well as these factors interaction.

It has also been pursued how itmaize crop behaves from the point of view of quality and efficiency index.

\section{MATERIALS AND METHODS}

Observations and determinations were performed in the experimental field of agricultural 
technology from NARDI Fundulea,Călăraşi County, in not irrigated system. Given the importance of maize and local climatic conditions, has been organized a group for the study the experimental maize crop productivity and quality in natural conditions. The experiment was located on a uniform land in terms of fertility and landscape, on a chernozem soil.

The total area of experience was of 7,056 $\mathrm{m}^{2}$, the surface of a parcel experiment was $168 \mathrm{~m}^{2}$, and the harvested area was $112 \mathrm{~m}^{2}$. Influencing factors and variations of these factors were the following: A. soil ground tillage

A1 - autumn plowing;

A2 - spring plowing;

A3 - disking.

B. nitrogen and phosphorus fertilization

B1 - N0P0;

B2 - N120P70.

C. studied hybrid

C1 - Partizan;

C2 - Opal.

The experimental module was three factorial, placed according to subdivided parcels method in three repetitions $3 \times 3 \times 2$.

The experimental results obtained were statistically processedusing the variance analysis method.

The location of culture was done within 4-year crop rotations, ensuring in this way a significant reduction of harmful pathogens and weed infestation hardly controlled (Sin et al., 1975).

For that purpose they have been organized plots sized to provide the efficient use of mechanization and the diversification of rotation with higher possibilities to adapt to any changes in cropping patterns.

In crop rotation, maize followed wheat crop.

In the experience it has been used biological material consisting of Romanian maize hybrids, both made at NARDI Fundulea. These hybrids meet the culture area and new technologies, being well known the use of genotypes without an accurate technology cannot provide production and quality performance, and without a valuable genotype best part is lost in the effectiveness of new technologies implementation. Romanian hybrids under analysis were Partizan and Opal, having the following features:
» Partizan. Simple hybrid, semi-erected leaves, red rachis, yellow grains, a middle vegetation period, approved and registered in 1998.

Zoning: is suitable for cultivation in the plains of the south and west of the country, in plateau or hilly areas surrounding them.

Vegetation period: from sowing to maturity is 130 days, falling within FAO 470 - 480 maturity group.

Description: The plant is robust, relatively high with an average height of $245 \mathrm{~cm}$ and $101 \mathrm{~cm}$ from maize cob insertion from the ground surface.

Cob is well developed with $18 \mathrm{~cm}$ length, $4.3 \mathrm{~cm}$ in diameter in the middle, 14 to 16 rows of grains, an average weight of 188 grams and a grains yield of $84 \%$. Grains are dentate, 1000 Grain Weight of $280 \mathrm{~g}$ and average protein content on $10,36 \%$, starch $71,97 \%$, and $4,32 \%$ fat, good for the fast drying ( $*$ Varieties/hybrids Official catalog of Romania, 2010).

Physiological characteristics: Good resistance to drought, heat and grains shriveled, and to the fall and breaking of stems.

Specific agronomic requirements: optimal plant density is 50,000 plants/ha not irrigated and 70.000 plants/ha irrigated.

Economic efficiency: in normal culture conditions, the production of non-irrigated gave $7,200-10,350 \mathrm{~kg} / \mathrm{ha}$, and the irrigated 11,100$15,100 \mathrm{~kg} / \mathrm{ha}, 3$ years average harvest. The highest harvests were of $11,500 \mathrm{~kg} /$ ha not irrigated and $16,840 \mathrm{~kg} / \mathrm{ha}$ irrigated.

» Opal. Simple hybrid, semi early, yelloworange grains andsmooth teem, homologated in 1994.

Zoning: is suitable for cultivation in the plains and plateau in the south and west and hilly areas south of the country.

Vegetation period: from sowing to maturity the period is 131 days, falling within FAO 420 430 maturity group.

Description: The plant is vigorous, relatively short, semi-erected leaves, red rachis, with an average height of $255 \mathrm{~cm}$ and $106 \mathrm{~cm}$ from maize cob insertion from the ground surface. Cob is large, cylindrical, with an average length of 20.5 $\mathrm{cm}$, thickness of $4.2 \mathrm{~cm}$, weight of $240 \mathrm{~g}, 14-16$ layers of grains and grain yield of $84 \%$. Grains are dentate, 1000 Grain Weight of $336 \mathrm{~g}$ and average protein content on $12.0 \%$, starch $71.90 \%$, and 
$4.32 \%$ fat, good for the fast drying (Sarca et al., 1995).

Physiological characteristics: it has good resistance to drought, heat, stems falling and breaking at maturity, as well as against the attack of European Maize Borer (Ostrinianubilalis).

Specific agronomic requirements: optimal density not irrigated is 50,000 plants/ha and 70,000 plants/ha for irrigation.

Economic efficiency: in normal culture conditions, not irrigated average grain harvest isof $10,000 \mathrm{~kg} / \mathrm{ha}$ (plain area) and irrespectively 8,500 $\mathrm{kg} / \mathrm{ha}$ (hilly area), and irrigatedof $15,000 \mathrm{~kg} / \mathrm{ha}$.

\section{RESULTS AND DISCUSSION}

Processing of primary data was performed in 2012, by weighing each variant harvest. It consisted in the removal of studied repetitions, realizing the average per variant, then loss and impurities reduction and reporting at surface unit.

Concomitantly researching the influence of several factors on production experiences poly factorial allow to study both the influence of each factor separately, and their combined effect application (Gologan et al., 1981).

So, the analysis of variance in the experience of the influence of soil tillage, fertilization and the maize hybrid harvest is shown in Table 1, from which can be seen both the significant differences for each of the three factors and the interaction between them, respectively tillage $\mathrm{x}$ hybrid, fertilization $\mathrm{x}$ hybrid and tillage $\mathrm{x}$ fertilizer $\mathrm{x}$ hybrid.

Tab. 1. Variance analysis at the poly factorial experience of $3 \times 2 \times 2$ type on the influence of tillage, fertilization, and hybrid over the maize harvest

\begin{tabular}{|c|c|c|c|c|c|c|c|}
\hline \multirow{2}{*}{ Variant } & \multirow{2}{*}{ SP } & \multirow{2}{*}{ GL } & \multirow{2}{*}{$S^{2}$} & \multirow{2}{*}{$\mathrm{F}_{\mathrm{C}}$} & \multicolumn{2}{|c|}{$\mathrm{Ft}$} & \multirow{2}{*}{ Signification } \\
\hline & & & & & $5 \%$ & $1 \%$ & \\
\hline A & 935.2 & 2 & 467.60 & 25195.0 & 6.94 & 18.00 & $* *$ \\
\hline E. & 0.07 & 4 & 0.02 & & & & \\
\hline$B^{A}$ & 1331.0 & 1 & 1331,0 & $* * * * * * * *$ & 5.99 & 13.74 & ** \\
\hline$A \times B$ & 115.2 & 2 & 57.60 & 5892.1 & 5.14 & 10.92 & $* *$ \\
\hline$E_{0}$ & 0.06 & 6 & 0.01 & & & & \\
\hline$C^{b}$ & 69.7 & 1 & 69.70 & 6565.2 & 4.75 & 9.33 & ** \\
\hline$A \times C$ & 15.7 & 2 & 7.86 & 740.1 & 3.88 & 6.93 & ** \\
\hline $\mathrm{B} \times \mathrm{C}$ & 0.30 & 1 & 0.30 & 28.4 & 4.75 & 9.33 & ** \\
\hline $\mathrm{AxBxC}$ & 2.04 & 2 & 1.02 & 96.2 & 3.88 & 6.93 & $* *$ \\
\hline $\mathrm{E}$ & 0.13 & 12 & 0.01 & & & & \\
\hline
\end{tabular}

Tab. 2. Analysis of soil tillage influence on maize harvest $(\mathrm{kg} / \mathrm{ha})$

\begin{tabular}{ccccc}
\hline Variant & Harvest & $\%$ & Difference & Signification \\
\hline $\mathrm{A}_{1}$ - Autumn plowing & 4534 & 100 & & \\
$\mathrm{~A}_{2}-$ Spring plowing & 3982 & 88 & -553 & 000 \\
\hline $\mathrm{A}_{3}$ - disking & 3288 & 73 & -1250 & 000 \\
\hline & $\mathrm{DL} 5 \%=150$ & $\mathrm{DL} \mathbf{1} \%=260$ & $\mathrm{DL} 0.1 \%=480$ & \\
\hline
\end{tabular}

Tab. 3. Analysis of fertilization influence on maize harvest $(\mathrm{kg} / \mathrm{ha})$

\begin{tabular}{crrcc}
\hline Variant & Harvest & $\%$ & Difference & Signification \\
\hline $\mathrm{b}_{1}$-not fertilized & 3,327 & 100 & Control & - \\
\hline $\mathrm{b}_{2}-\mathrm{N}_{120} \mathrm{P}_{70}$ & 4,543 & 136 & 1,216 & $* * *$ \\
\hline & $\mathrm{DL} 5 \%=80$ & $\mathrm{DL} 1 \%=120$ & $\mathrm{DL} 0.1 \%=200$ & \\
\hline
\end{tabular}


Influence of soil tillage on maize harvest under the agricultural year 2012 can be found in Table 2 .

Influence of fertilization on maize harvest in terms of 2012 is found in Table 3.

The application dose of $\mathrm{N}_{120} \mathrm{P}_{70}$ fertilization in maize, it leads to a harvest of $4,543 \mathrm{~kg} / \mathrm{ha}$ comparing to the not fertilized control variant where it was obtained a harvest of $3,327 \mathrm{~kg} / \mathrm{ha}$. Nitrogen and phosphorus fertilizer application resulted in obtaining a production increase of $1,216 \mathrm{~kg} / \mathrm{ha}$, considered as very significant.

\section{CONCLUSION}

From analyzing the data collected and presented in the climatic conditions of 2012, highest production of $4,534 \mathrm{~kg} / \mathrm{ha}$ was obtained from version where has been used as basic ground work the autumn plowing.

Replacing this variant with spring plowing has reduced production by $553 \mathrm{~kg} / \mathrm{ha}$, the difference being highly significant. Also, the disking applied as a technologic link instead of autumn plowing caused a harvest decrease of $1,246 \mathrm{~kg} / \mathrm{ha}$, difference being considered very significant.

A summary of results concerning the influence of soil tillage over maize harvest depending on fertilizing and used hybrid, is shown in tables 4 and 5.

Comparing averages factor A graduations (soil tillage), not fertilized or fertilized, this being studied in the case of two hybrids (Partizan and Opal), results that the highest harvests are obtained in autumn plowing, fertilized $(5,330 \mathrm{~kg} /$ ha, irrespectively $5,157 \mathrm{~kg} / \mathrm{ha}$ ).

By using the technological link of spring plowing and fertilization with $\mathrm{N}_{120} \mathrm{P}_{70}$, in condition of 2012, average harvests obtained were lower than those of autumn plowing.

From the data submitted we observe a decrease in harvest in both hybrids (Partizan and

Tab. 4. Analysis of soil tillage on maize production depending on fertilizer and hybrid (kg/ha)

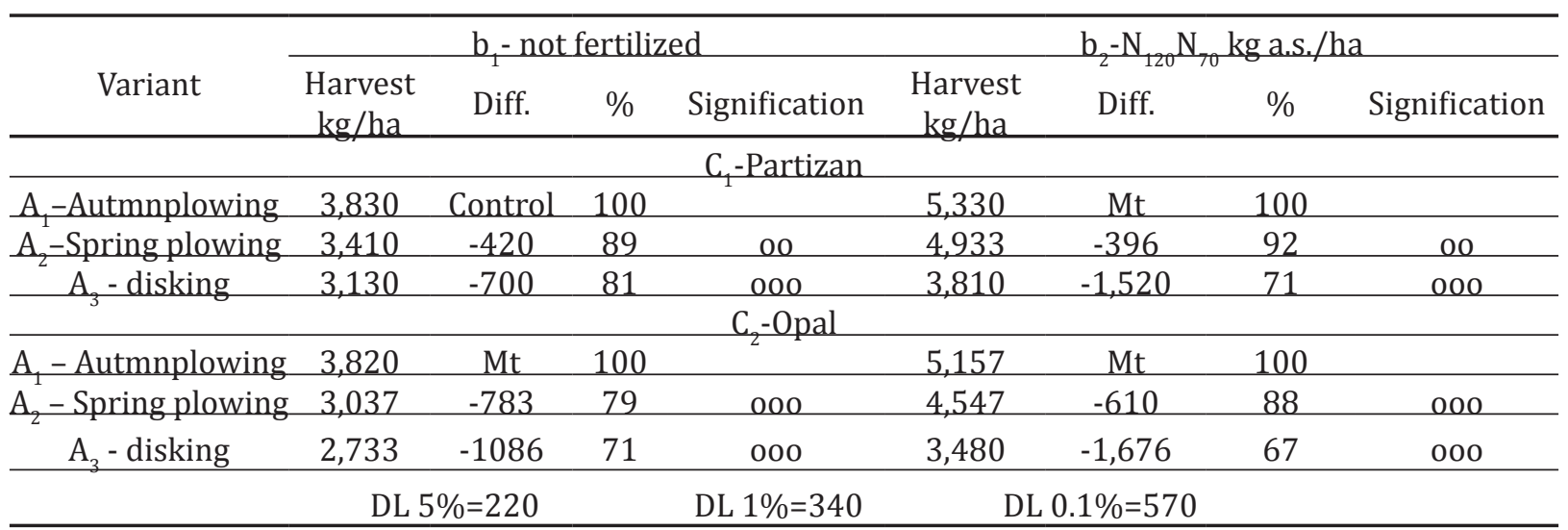

Tab. 5. Average harvests obtaines (kg/ha)

\begin{tabular}{|c|c|c|c|c|}
\hline \multicolumn{2}{|c|}{ Variant } & \multirow{2}{*}{$\frac{C_{1}-\text { Partizan }}{3,830}$} & \multirow{2}{*}{$\frac{\mathrm{C}_{2} \text { - Opal }}{3,820}$} & \multirow{2}{*}{$\begin{array}{c}\text { Harvest } \\
3,825\end{array}$} \\
\hline$A_{1}$ - Autmnplowing & $\mathrm{B}_{1}$-not fertilized & & & \\
\hline $\mathrm{A}_{2}-$ Spring plowing & $\mathrm{B}_{2}-\mathrm{N}_{120} \mathrm{P}_{70}$ & 5,330 & 5,157 & 5,243 \\
\hline \multirow{2}{*}{$\begin{array}{c}\mathrm{A}_{3} \text { - disking } \\
\mathrm{A}_{1}-\text { Autumnplowing }\end{array}$} & $\mathrm{B}_{1}-$ not fertilized & 3,410 & 3,037 & 3,223 \\
\hline & $\mathrm{B}_{2}-\mathrm{N}_{120} \mathrm{P}_{70}$ & 4,933 & 4,547 & 4,740 \\
\hline \multirow{2}{*}{$\mathrm{A}_{2}-$ Spring plowing } & $\mathrm{B}_{1}-$ not fertilized & 3,130 & 2,733 & 2,931 \\
\hline & $\mathrm{B}_{2}-\mathrm{N}_{120} \mathrm{P}_{70}$ & 3,810 & 3,480 & 3,645 \\
\hline \multicolumn{2}{|c|}{ Harvest (average) } & 4,073 & 3,795 & 3,934 \\
\hline
\end{tabular}


Tab. 6. Comparisons between the experimental factors under analysis variations

\begin{tabular}{|c|c|c|c|}
\hline \multirow{2}{*}{ Interaction of the experimental factors } & \multicolumn{3}{|c|}{ D.L. values } \\
\hline & $5 \%$ & $1 \%$ & $0.1 \%$ \\
\hline Comparisons between the variations of factor $\mathrm{A}$ & 150 & 250 & 480 \\
\hline Comparisons between the variations of factor B & 80 & 120 & 200 \\
\hline Comparisons between the variations of factor $\mathrm{C}$ & 70 & 110 & 150 \\
\hline Comparisons between the variations of factor A at the same variant of factor B & 180 & 300 & 530 \\
\hline Comparisons between the variations of factor A at the same variant of factor B & 110 & 160 & 240 \\
\hline Comparisons between the variations of factor $A$ at the same variant of factor $C$ & 180 & 280 & 490 \\
\hline $\begin{array}{l}\text { Comparisons between the variations of factor } A \text { at the same variant of factors B } \\
\text { and C }\end{array}$ & 220 & 340 & 570 \\
\hline
\end{tabular}

Opal) in the variants of spring plowing and disking, by comparison with the control (autumn plowing) with statistical provided values as distinct and very significant ranging from 420 to $1370 \mathrm{~kg} / \mathrm{ha}$ (Tab. 5, Tab. 6).

Noteworthy is the experimental version concernig the ground soil tillage (disking), recording the highest loss of production compared to the control, ranging from 1530 to $1660 \mathrm{~kg} / \mathrm{ha}$. Concerning the hybrids output concerning the interaction of the studied factors, we can see a similar behavior of both hybrids, the harvests being comparable.

In conclusion, given a relatively droughty year, due to uneven distribution of rainfall associated with high temperatures, maize culture technology in relation to the studied variations consists of seedbed preparation after autumn plowing as basic work, crop fertilizing with $\mathrm{N}_{120} \mathrm{P}_{70}$ and use of the Partizan hybrid.

\section{REFERENCES}

1. Bîlteanu Gh (1989). Phytotechnics 1:20-136

2. Cristea M,Căbulea I, Sarca T (2004). Maize. Monographic Study. Romanian Academy Publishing House.

3. Gologan I, Dornescu A (1981). Plant Breeding Course. Agronomic Institute Ion Ionescu de la Brad Iaşi :350.

4. Muntean SL, Borcean I, Axinte M, Roman Gh (1995). Phytotechnics. Didactică şi Pedologică R.A. Publishing House, Bucharest.

5. Partal E, Zaharia GV (2008). Results on the effects of fertilization on the main field crops. Anals of NARDI Fundulea (LXXIV):111-118.

6. Petcu Gh, Petcu E, Sin Gh, Chirnogeanu I (1997). The influence of soil tillage and nitrogen fertilization on mineral nutrition of maize. Romanian Agricultural Research 7-8:63-69.

7. Sarca T, Cosmin O, Ciocazanu I, Bica N, Bâgiu C (1995). Maize breeding for drought tolerance. In Maize Breed. Prod. And Utilization - 50 years of maize Res. Inst. Zemun. Yugoslavia:341-345.

8. Sin Gh, Pintilie C (1975). Research on the influence of crop rotation on weed growth of field crops. Annals of RICTP Fundulea (XL Series B).

9. *** (2010). The official catalog of varieties (hybrids) of crops in Romania. 